\title{
Effect of Rasayana In Covid-19 Cases: An Observational Study
}

\author{
Rutuja Rajabhau Jane*¹, Vrushali P. Khandekar ${ }^{2}$, Sumeeta S. Jain ${ }^{3}$ \\ ${ }^{1}$ PG Scholar, ${ }^{2}$ Assistant Professor and Guide, ${ }^{3} \mathrm{HOD}$ and Professor, \\ Department of Swasthavritta and Yoga \\ Government Ayurved College, Nagpur, M. S. India
}

*Author Correspondence: Contact No: 9022212243; Email: rutujajane@ gmail.com

\begin{abstract}
:
Aim: Evaluation of effect of Rasayana in COVID-19 Cases

Background: The pandemic of novel corona virus disease(COVID-19) created havoc worldwide. The global community is facing the rapidly spreading pandemic. WHO is trying hard to contain effects of COVID-19 to a minimum. At this moment whole world needs appropriate line of management. So, it needs to be seen that any significant leads can be procured through the intervention of Ayurveda. Rasayana is the rejuvenation therapy of body. It is one of the comprehensive disciplines of Ayurveda which consist of specialized use of herbs, herbo-mineral formulation, which target at Dhatu Samya.
\end{abstract}

Methodology: This is an observational study of 10 home quarantine cases of COVID-19 of age greater than 20 years. They were mild symptomatic who received only ayurvedic medicine. Graphically represented data is observed and analysed the improvement in symptoms and recovery from COVID-19. Data is graphically represented.
Result: 7 out of 10 patients in this study were relieved from symptoms within first 15 days of treatment exhibiting $70 \%$ recovery. 3 out of 10 patients in this study were relieved from symptoms after 15 days of treatment exhibiting $30 \%$ recovery.

Conclusion: The Rasayana Chikitsa mentioned in Ayurvedic text is sufficient to improve mild infection of COVID-19.

Keywords: COVID-19, Rasayana, Rejuvenation Therapy.

\section{Introduction}

The pandemic of novel corona virus disease (COVID-19) created havoc worldwide. It is caused by severe Acute Respiratory Syndrome corona virus-2 (SARS-Cov-2). ${ }^{[1]}$ The global community is facing the rapidly spreading pandemic. The corona virus primarily spread among the people during close contact, most often through small droplets produced by sneezing, coughing and talking. Less commonly infected by touching contaminated surface. Common symptoms include fever dry cough, 
fatigue, anosmia, difficulty in breathing and tastelessness. ${ }^{[2]}$ Complication may include pneumonia and ARDS. ${ }^{[3]}$ WHO is trying hard to contain effects of COVID-19 to a minimum. At this time whole world needs appropriate line of its management. So, it needs to be seen that whether any significant recovery can be possible through the intervention of Ayurveda or not.

Rasayana is the rejuvenation therapy of body. It is one of the comprehensive disciplines of Ayurveda which consist of specialized use of herbs, herbo-mineral formulation, food articles and life style which aims at Dhatu Samya(homeostasis). ${ }^{[4]}$ Rasayana is of two types Bheshaj and Abheshaja. Bheshaj Rasayana is divided into two types 1. Swasthasyaojaskar which means it helps to improve immunity of healthy individuals. ${ }^{[5]}$ 2. Aartasya Roganut means to resolve disease condition. ${ }^{[5]}$ Rasayana helps to improve physical and mental strength by achieving homeostasis of seven Dhatu. Longevity, improve memory, grasping power, health, complexion and voice are the benefits of Rasayana. [6] It delays the age by nourishing the body and promote longevity. Thus we can plan for Rasayana therapy right from birth which may be introduced in future immunization schedule.

Ministry of AYUSH in India has propagated use of traditional Indian system of medicine including Ayurveda for prophylactic use as well as an alternative system of medicine to provide an effective and holistic approach towards COVID-19. As per Ayurveda COVID-19 corelates with Sannipataj Jwara, one of the types of fever mentioned. ${ }^{[7]}$ It also bears analogy with
Rajyakshma (Shosha) ${ }^{[8]}$ and Dushtya Pratishyaya $^{[9]}$ due to Agnimandya. This COVOD-19 infection affects digestive system and hamper the immune system (Oja Kshaya). In Ayurveda it is said that the root cause of all disease is Mandagni which leads to insufficient immunity. Thereby, from this study we can say that the Rasayana Chikitsa mentioned in Ayurvedic text is sufficient to improve mild infection. The aim of this study was to evaluate the role of Rasayana Chikitsa in COVID-19.

\section{Material and Methods}

Study design: Observational Study

\section{Study population}

The present study conducted on 10 patients, irrespective of sex, religion. The medical data of 10 patients who received only Ayurvedic treatment between March-May 2021. These patients, after being confirmed as COVID-19 positive through RTPCR of nasopharyngeal \& oropharyngeal swab samples, were isolated at their home. Clinically these cases were asymptomatic to mildly symptomatic in nature. None of these patients had of any international travel history. Consent had been taken. Primary outcome of this study was symptomatic resolution of COVID-19 Infection.

\section{Inclusion Criteria -}

1. Patients who receive only Ayurvedic treatment.

2. Age, 20-60 years

3. Asymptomatic to mildly symptomatic patients

4. RTPCR positive

\section{Methodology}

This was an observational study of ten COVID-19 patients. They were asymptomatic or mildly symptomatic, treated with only Ayurvedic medicine and were home quarantined. The data 
included previous disease, symptoms of present disease, vital signs. Complete treatment received during quarantine period was recorded as well as analysed. The Ayurvedic medicine included only
Rasayana taken orally. The dosage were decided by their own physician. The patients were observed for symptomatic improvement.

Treatment

Table 1: Recommended Daily Ayurvedic Treatment for COVID-19 Patient

\begin{tabular}{|l|l|l|}
\hline Sr. No & Medicine & Dose and Anupaan \\
\hline 1 & Chyavanprash & $10 \mathrm{gm}$ with milk/ Once a day \\
\hline 2 & Guduchi Ghanvati & $500 \mathrm{mg}$ twice daily with warm water 15 days \\
\hline 3 & $\begin{array}{l}\text { Rasayana Churna } \\
\text { (Gokshur }+ \text { Aamalki }+ \text { Guduchi })\end{array}$ & $\begin{array}{l}3 \mathrm{gm} \text { powder twice daily with honey for one } \\
\text { month }\end{array}$ \\
\hline 4 & Ayush Kwath & $15 \mathrm{ml}$ twice daily for 1 month \\
\hline
\end{tabular}

Table 2: Action of Ayurvedic Drugs

\begin{tabular}{|l|l|l|}
\hline $\begin{array}{l}\text { Sr. } \\
\text { No }\end{array}$ & Medicine & Action \\
\hline $\mathbf{1}$ & Chyavanprasha $^{[10]}$ & $\begin{array}{l}\text { Anti-oxidant, Vit-C rich, Anti-bacterial, Antiviral, anti- } \\
\text { inflammatory, antiallergic, vasodilator and Rasayana }\end{array}$ \\
\hline $\mathbf{2}$ & $\begin{array}{l}\text { Guduchi Ghanvati } \\
\text { (Tinospora cardifolia) } \\
{[11]}\end{array}$ & $\begin{array}{l}\text { Anti-inflammatory, Anti-oxidant, Anti-microbial, Anti- } \\
\text { allergic, Hepatoprotective, Immunomodulatory, } \\
\text { Antipyretic, Anti-infective, Anti-Hyperglycaemic, } \\
\text { Diuretic and Rasayana }\end{array}$ \\
\hline $\mathbf{4}$ & Rasayana Churna $^{[12]}$ & $\begin{array}{l}\text { Anti-depressant, Immunomodulatory, Anti-diabetic, } \\
\text { Anti-hypertensive, Anti-inflammatory, Anti toxic effect, } \\
\text { Anti-arthritic, Anti-microbial, Anti-oxidant }\end{array}$ \\
\hline $\mathbf{5}$ & Ayush Kwath & $\begin{array}{l}\text { Immunomodulatory, Antiviral, anti-platelet, Anti- } \\
\text { atherosclerotic, Hepatoprotective, reno-protective }\end{array}$ \\
\hline
\end{tabular}

Study completion Criteria- The study completion criteria included regaining normal body temperature, relief from cough, headache, fatigue, sore throat, nasal congestion. Alleviation of COVID19 Symptoms were monitored for at least 72 hours to ensure no relapses were approved the study.

\section{Observations}

\section{Patients evaluation}

At baseline, the clinical symptoms of the patients such as body temp, cough, bodyache, headache, sore throat, nasal congestion were monitored. Subsequently, these parameters were regularly tracked along with any visible symptoms or any side effects of the treatment.

\section{Data Presentation}

Overall and group-wise age distributions are represented as percent COVID-19 cases in different age range, genders distribution within each age group is shown as percent male / female of the total patients within that particular group and as shown as bar graphs. Gender distribution within study groups is represented as pie chart. Resolution of symptoms within 30 days to represented as proportional bar graphs. Percent 
recovery within 30 days to represented as recovery was observed. proportional line graphs. The trend in

\section{Result}

Fig.1 Age distribution among the observed Patients.

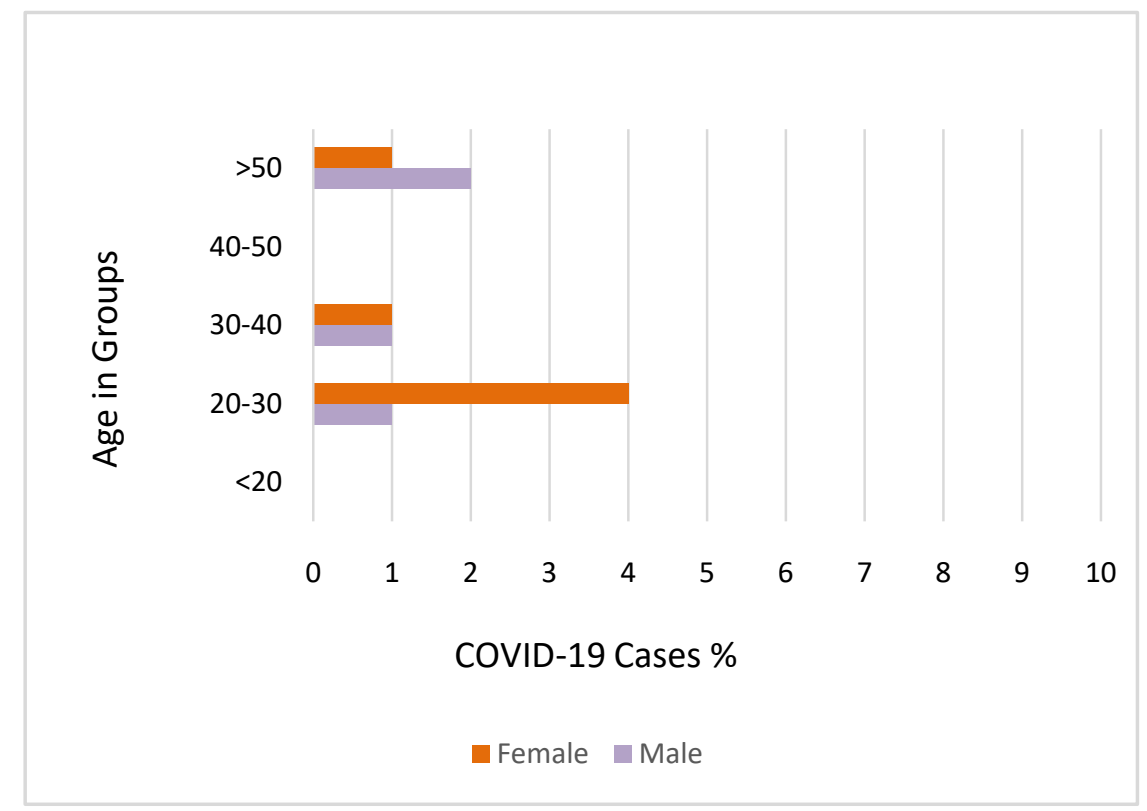

In this study $50 \%$ population is from age group 20-30 years out of which $25 \%$ is male and $66 \%$ is female. $20 \%$ population is from the age group 30-40 years out of which $25 \%$ belong to male and $17 \%$ belongs to female. $30 \%$ population is belongs to age group greater than 50 years out of which $50 \%$ is male population and $17 \%$ is female population.

\section{Fig.2 Gender Distribution}

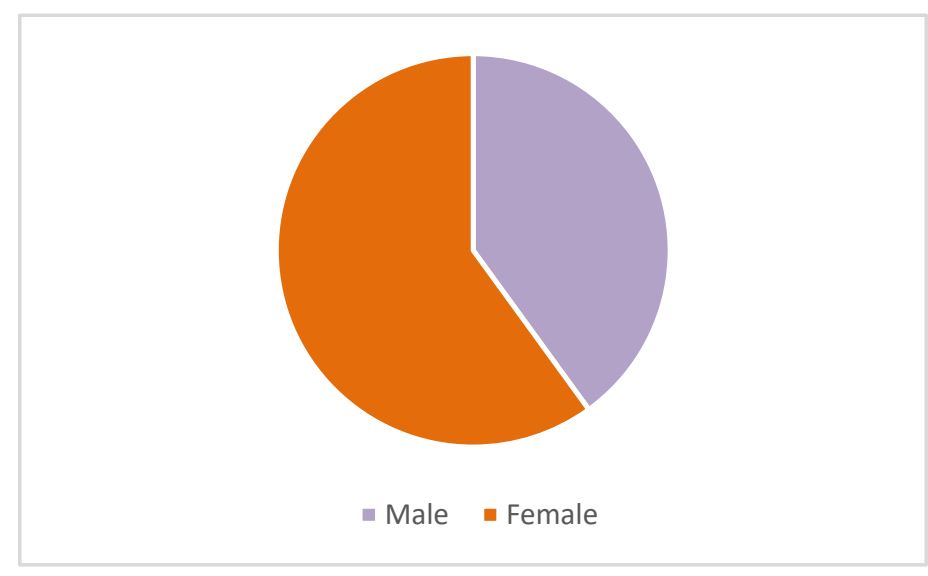

In this study $60 \%$ population belongs to female and $40 \%$ belongs to male. 
Fig.3 Days for Resolution of symptoms

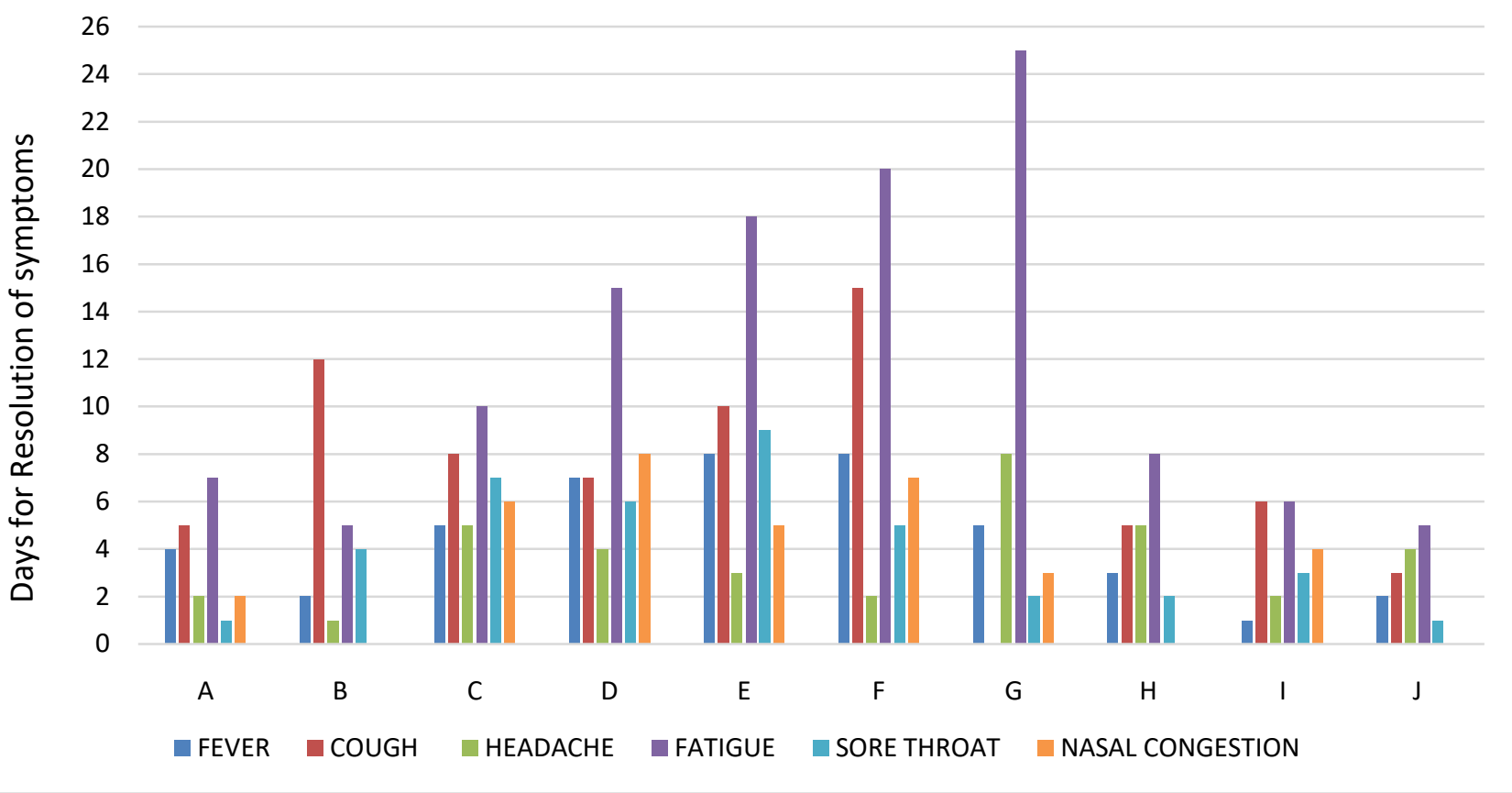

$70 \%$ case recovered from fever up to $5^{\text {th }}$ day. $60 \%$ cases recovered from cough up to $7^{\text {th }}$ day. $70 \%$ case recovered from headache up to $4^{\text {th }}$ day. $60 \%$ case recovered from fatigue up to $12^{\text {th }}$ day.
$70 \%$ case recovered from sore throat up to $5^{\text {th }}$ day. $57 \%$ case recovered from nasal congestion up to $5^{\text {th }}$ day.

Fig.4 Effect of Rasayana on the recovery of COVID-19 patients regarding time.

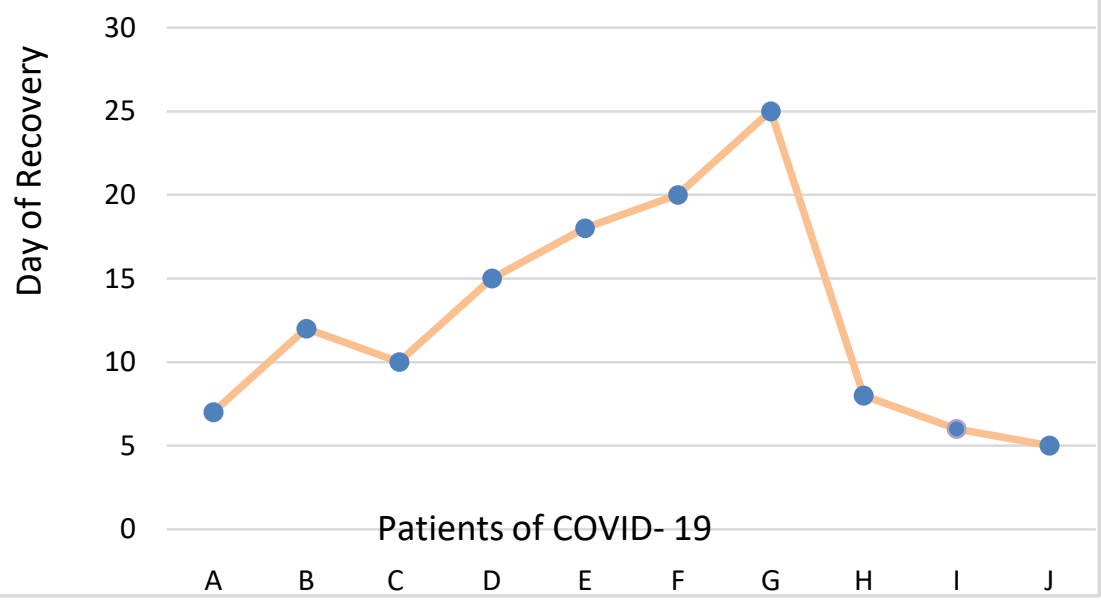

7 out of 10 patients in this study were relieved from COVID-19 symptoms within first 15 days of treatment exhibiting $70 \%$ recovery. 3 out of 10 
patients in this study were relieved from COVID-19 symptoms after 15 days of treatment exhibiting 30\% recovery.

\section{Result}

Primary outcome of this study was the Symptomatic relief from COVID-19. Data Collected Over the Period of 3 Months, shows that patients exhibited symptomatic relief within first 30 days of Treatment. No visible adverse effects were observed. This indicates safe symptomatic resolution among those treated with Rasayana alone.

\section{Discussion}

The main aim of the study was to evaluate the potential of Ayurvedic medicine against COVID-19 infection. Ayurveda has traditional roots and it is well documented. The medicines taken by the patients in this study were based on the information from Ayurvedic texts and WHO recommendation. This was an observational study to check the hypothesis that the medicine used in Ayurvedic treatment can improve asymptomatic to mild symptomatic cases of covid-19.. No critical and co-morbid case was included. All the patients of COVID-19 receiving only Ayurvedic medicine were completely recovered within 30 days of treatment. A regular intake of Chyavanprash strengthens the trachea-bronchial tree and hence improves the immunity and functioning of the respiratory system. It helps to treat respiratory infections, allergic cough, asthma, bronchospasm, rhinitis, seasonal or nonseason respiratory disorders, common cold, and tuberculosis, and thus strengthens the respiratory system. It is also used as antitubercular drugs to augment their bioactivity and prevent their side effects. Guduchi Ghanvati was effective in viral clearance and reducing hospital stay compared to standard care. It usage as an immunomodulator, antioxidant, anti-microbial and anticancer properties made it an interesting focus for Covid-19 management. It has feasible efficacy of Guduchi Ghanvati against coronavirus in general and SARS-CoV-2 specifically. The effect of Rasayan churna mentioned in Ashtanghrudaya has a property like it is used in maintenance of sexual Vigor (Vrushya), it provides Stability (Sthiratva), it is used in peacefulness and for eradication of diseases (Shant Vikar dukkham), it maintain Balance (Samahatva), also acharya mentioned that if it is used regularly it can provide long healthy life (Shatam Jivati). Rasayan Churna and its contained we can used it as a best rejuvenation therapy, as it has a property like, anti-depressant, Immunomodulatory, Anti- diabetes, antihypertensive, anti-inflammatory, Anti-toxic effects, Anti-arthritic, Anticancer effects, Anti-microbial effect, and Anti-oxidant effect. So it should be taken in day to day life during Covid -19 out break for the protection of the health and to reduce the stress level in normal individual. And in symptomatic and in asymptomatic patients it is used as immunomodulant to boost the immunity. Ayush Kwath due to its antiviral, immune-modulatory, antioxidant, antiinflammatory, anti-platelet, antiatherosclerotic, hepato-protective, renoprotective properties; seems to be effective in regulating immunity for the prevention and reduction of viral disease complications. The observation that only Ayurvedic medicines were capable of safe symptomatic improvement of COVID-19. 


\section{Conclusion:}

Patients with mild symptoms of COVID19 were symptomatically relieved safely by Rasayana medicine treatment.

\section{Reference}

1. Mayoclinic.org [homepage on internet]. U.S:Mayoclinic;1998-2021 Available form: http://www.mayoclinic.org

2. cdc.org [homepage on internet]. USA: Cenres for Disease Control and Prevention;2019 [Upadated on Feb 2021] Available form: http://www.cdc.gov

3. webmed.org [homepage on internet]. Web edicine;Available from: http://www.webmd.com

4. Goyal M. Rasayana in perspective of the present scenario, Ayu, 2018;39(2):63-4 Available from: http://www.ayujournal.org/text.asp?2018/39/ 2/63/250779

5. Agnivesh, Charak Samhita of Acharya Charak, Dridhabala krit, edited by Vaidya Vijay Kale, Chikitsasthan, Ch. 1, Ver. 4, $1^{\text {st }}$ edition, Vol.2, Delhi: Chaukhamba Sanskrut Prakashan, 2014; p.4

6. Agnivesh, Charak Samhita of Acharya Charak, Dridhabala krit, edited by Vaidya Vijay Kale, Chikitsasthan, Ch.1, Ver. 7, $1^{\text {st }}$ edition, Vol.2, Delhi: Chaukhamba Sanskrut Prakashan, 2014; p.5

7. Agnivesh, Charak Samhita of Acharya Charak, Dridhabala krit, edited by Vaidya Vijay Kale, Chikitsasthan, Ch. 3, Ver. 89-90, $1^{\text {st }}$ edition, Vol.2, Delhi: Chaukhamba Sanskrut Prakashan, 2014; p.83
8. Agnivesh, Charak Samhita of Acharya Charak, Dridhabala krit, edited by Vaidya Ravidatta Tripathi, Nidansthan, Ch. 6, Ver. 14, Reprint, Vol.1, Delhi: Chaukhamba Sanskrut Pratishthan, 2013; p.528

9. Agnivesh, Charak Samhita of Acharya Charak, Dridhabala krit, edited by Vaidya Vijay Kale, Chikitsasthan, Ch. 26, Ver. 107109. $1^{\text {st }}$ edition, Vol.2, Delhi: Chaukhamba Sanskrut Prakashan, 2014; p.629

10. Sharma R, Martins N, Kuca K, Chaudhary A, Kabra A, Rao M, et al. Chyawanprash: A Traditional Indian Bioactive Health Supplement, Biomolecules, 2019;9(5):161

Available

from: http://doi.org/103390/biom9050161

11. Upadhyay A, Kumar K, Kumar A, Mishra H. Tinospora cardifolia (Willd.) Hook.f. and Thoms. (Guduchi)- Validation of the Ayurvedic Pharmacology through experimental and clinical studies, International Journal of Ayurveda Research, 2010;1(2);112-121

12. Deshpande A, Deshpande M. Role of Rasayan churna in outbreak of COVID-19 as preventive and curative aspect, Intrenational Journal of Research in Pharmaseutical Science,2020;11(SPL1),1208-1212 http://doi.org/10.26452/ijrps.v11iSPL1.3594

13. Gautam S, Gautam A, Chhetri S, Bhattarai U. Immunity Against COVID-19: Potential role of Ayush Kwath, Journal of Ayurveda and Integrative Medicine, 2020 Available from:

http://doi.org/10.1016/j.jaim.2020.08.003

DOI:

Conflict of Interest:

Non

https://doi.org/10.52482/ayurline.v5i03.585

Source of funding: Nil

\section{Cite this article:}

Effect of Rasayana In Covid-19 Cases: An Observational Study

Rutuja Rajabhau Jane, Vrushali P. Khandekar, Sumeeta S. Jain

Ayurline: International Journal of Research In Indian Medicine 2021; 5(4):01-07 